\title{
ESCO Project for Buildings of Government Agencies in Thailand
}

\author{
Monchai Prukvilailert ${ }^{1}$, Prapat Wangskarn ${ }^{1}$ \\ 1 Thammasat University, Thailand
}

\begin{abstract}
In Thailand, Department of Alternative Energy Development and Efficiency (DEDE) have organized the ESCO project to promote and encourage the use of machinery, materials and equipment having high efficiency for government buildings. ESCO company provides the invest and management for changing equipments in the buildings. In this paper, the evaluation of the project has been presented. The potential of electricity savings is about 77 million kwhr/year. It can reduce imports of crude oil about 6.58 thousand tons of crude oil (Ktoe/year). The budget to invest is BHT 1,504 million, with an average payback period of 4.85. However, we found that the establishment of the budget is the barriers. The recommendations and solutions using legal process have been presented to proceed the project in the future.
\end{abstract}

\section{Introduction}

On March 20, 2013 the Cabinet has approved the Government agency to implement measures to reduce energy consumption by at least $10 \%$ according to the regulation of energy development and promotion in Thailand[1]-[3]. Results from the survey data of the project and oversee the conservation of energy in the building sector about 800 buildings. The potential energy savings of buildings of government agencies that have the potential to reduce crude oil import up 75 ktoe per year (BH 1,800 million per year) by investing more than BH 6,300 million to solve the limitations of the government in the budget of up to 6,300 million baht in using highperformance equipment. Department of Alternative Energy Development and Efficiency DEDE, Ministry of Energy, have launched the project management in order to save energy in the building sector using Energy Service Company (ESCO) operating by the private sector. It offers a full range of energy conservation. For the cost of the operation, ESCO companies will be paid in amount of the cost savings that can be reduced.

Mechanism in Business Management (Energy Service Company: ESCO) would mean providing turnkey energy conservation by counselling, proposing project, project management, engineering design, energy Analysis, equipment installation and operation and find funding. The distinguished characters of the mechanism ESCO is to guarantee energy savings from the implementation of energy conservation projects. Compensation will be paid to the buildings if saving energy is not in accordance with agreed. Thus buildings confidence that ESCO mechanism is able to used to get energy saving worth all the money that were paid to the budget. It can reduce energy consumption and energy expenditures down, certainly in the future. However, there are policy barriers of ESCO for government buildings such as, the inability to establish the comprehensive budget package (Turnkey) and the implementation of commitments over the fiscal year.

In order to resolve such obstacles, National Energy Policy Council (NEPC) On March 23, 2013 has approved a pilot project to manage energy-saving (ESCO) in government buildings. The project management to save power by ESCO system in buildings will have to sign an agreement deal with the third parties including DEDE, Metropolitan Electricity Authority (MEA)/Provincial Electricity Authority (PEA) and government buildings. MEA and PEA act as ESCO companies that have to survey and design measures to conserve energy. Furthermore, MEA\PEA have the responsibility for defining hardware configuration, preparing an energy agreement, equipment installation as well as evaluation of the economy. MEA $\backslash$ PEA will be charged the managing cost adding to monthly electric bill of buildings. The pilot project was in demand. Therefore, more than 50 government buildings signed a memorandum on cooperation in the implementation of project management in order to save energy by ESCO especially for academic sector and Hospital.

\section{Procedure}

Energy Service Companies (ESCO) will act as turnkey implementation of energy conservation to the buildings to achieve the energy savings. ESCO acts for monitoring of energy (Energy Audit) before implementing, construction Management services, project 
financing, project guarantees, equipment maintenance and servicing and other services [11]-[12].

Figure 1 shows the allocation of an energy performance contract. The first action (the baseline year) buildings must pay all utility bills. During the implementation of the contract performance, energy costs decreases by the amount of the energy savings will pay to the Energy Service Companies (ESCO) for a fee to carry out investment. The remainder will be for buildings throughout the lifetime of the energy performance contract project. When end of the contract term, the total energy saving will return to building only.

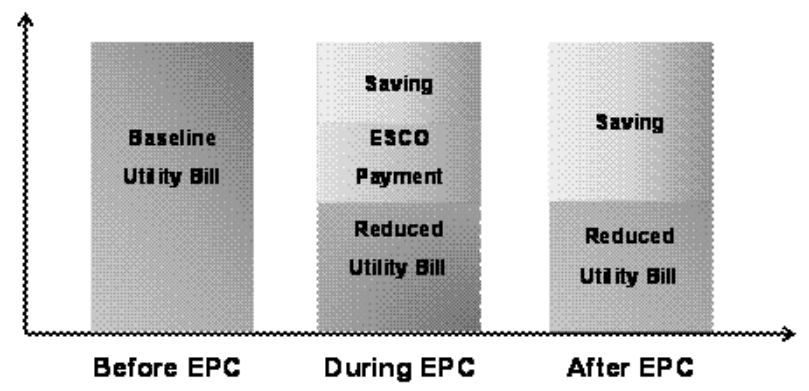

Figure 1 Allocation of the energy performance contract

In Figure 2, the process of implementation can be explained as follow:

1. ESCO selection (MEA or PEA)

2. Energy Audit

To determine the energy audit, ESCO company surveyed and monitored the power consumption of the buildings before defining the energy saving measures, especially the specific energy consumption (Specific Energy Consumption, SEC). After the survey and collect energy consumption data, ESCO analyzed to find ways to conserve energy. The process can be shown in detail as follow:

(1) Determine primary (Preliminary Audit) which assesses energy use scales to determine the potential of reducing the energy consumption. In addition, the preliminary examination would have cost for ESCO.

(2) Determine the specific type (single purpose or targeted Energy Audit), which monitored only one device or system thoroughly such as changing light bulbs, a variable speed drive (VSD) and replacement of boilers (Boiler) and chiller (Chiller).

(3) Check to cover all (comprehensive audit), which details the use of energy and to prepare plans for energy conservation projects carefully. It will consider the impact of the various systems used to power the buildings according to weather, working hours and other variables associated with energy use. Advantages of the inspection are a comprehensive analysis of the costs and savings in detail. Including the impact of one system to another system, the disadvantage is the relatively high cost.

3. Energy savings proposal

4. Energy performance contract

In this project, the energy performance contract has been chosen based on guaranteed saving method. Therefore, buildings must perform financing for the project by themselves or borrow money from financial institutions. In this case, Energy Service Companies (ESCO) will guarantee the performance of the economy (saving performance) to the clients or agencies. Usually, the savings will amount, as well as the clients must pay back to the lender.

5. Project Implementation

5.1 Construction Management services

5.2 Project Financing

5.3 Project guarantees

5.4 Equipment maintenance and servicing

5.5 Other services

6. Measurement and verification

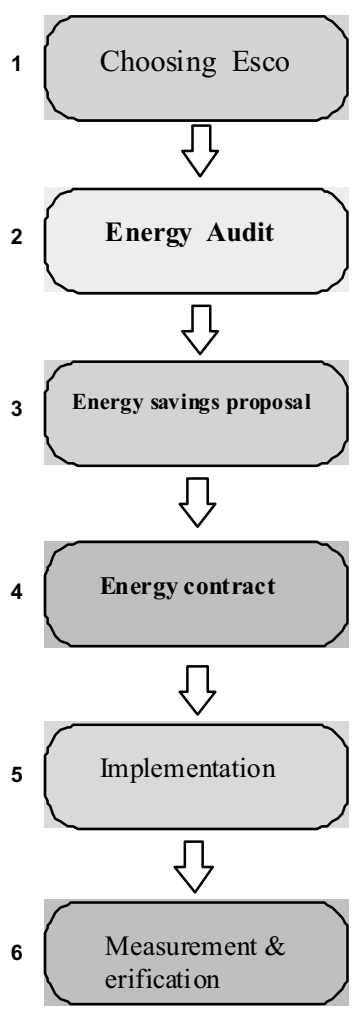

Figure 2. Operational processes using ESCO

There are 53 buildings ( 26 academic buildings, 26 Hospitals and 1 office buildings) joined the project. They have implemented energy saving measures using ESCO system.

\section{Potential savings}

The results showed that the building sector, signed a memorandum of number 53. This government buildings have the potential of electricity savings about 77 million $\mathrm{kwhr} /$ year. It can reduce imports of crude oil about 6.58 thousand tons of crude oil (Ktoe) per year. This represents the cost of BHT 310 million per year. The budget to invest is BHT 1,504 million, with an average payback period of 4.85 years as shown in Table 1 .

For this project, four types of equipments are promoted to implement.

1. High efficiency boiler

2. High efficiency chillers 
3. High efficiency air conditioning units

4. LED lamp

Table 1. Potential savings of 53 buildings.

\begin{tabular}{|c|r|l|l|}
\hline Type & $\begin{array}{l}\text { Electricity } \\
\text { saving } \\
(\mathrm{kWh} / \mathrm{y})\end{array}$ & $\begin{array}{l}\text { Thermal } \\
\text { saving } \\
(\mathrm{MJ} / \mathrm{y})\end{array}$ & $\begin{array}{l}\text { Energy saving } \\
(\mathrm{ktoe} / \mathrm{y})\end{array}$ \\
\hline Hospital & $30,152,669$ & $1,227,937$ & 2.59 \\
\hline Academic & $46,407,574$ & 0 & 3.95 \\
\hline Office & 294,547 & 0 & 0.02 \\
\hline total & $76,854,820$ & $1,227,937$ & 6.56 \\
\hline
\end{tabular}

By tracking the status of the progress for all buildings in the project, we found that only one buildings (Rajamangala University, Lanna campus) can achieved the success of the implementation which is operated by budget of its own income. The results were unexpected comparing with the previous projects [6]-[12].

We have collected the information to fix the problems in the disbursement of funds. The building can be divided into two types of government. Type One, government building have their own income and budget. Type Two, government buildings received all budget from the government.

Building Type 1 (Academic buildings) can implement the project by spending money on their own. Buildings can implement immediately without waiting for the correct payment procedures. Most are academic buildings. The potential of electricity savings is BHT 46 million per year. Imports of crude oil can be reduced up to 3.96 tons of oil per year(ktoe), representing a cost of BHT 188 million per year. The budget to invest is BHT 1,064 million, with an average payback period of 5.67 years.

Building Type 2 (Hospital) only has an annual government statement of expenditure. This will have to wait to resolve disbursement procedures. However, the buildings have the potential of electricity savings is BHT 30 million units per year. Imports of crude oil can be reduced up to 2.63 tons of oil per year (Ktoe), representing a cost of BHT 122 million per year. The budget to invest is BHT 445 million, with an average payback period of 3.62 years. Table 2 show the number of equipments by type.

Table 2. Equipment by Type for Building Type 1 and Type 2 .

\begin{tabular}{|l|r|r|}
\hline Type of equipment & $\begin{array}{r}\text { Building Type 1 } \\
\text { (Academic) } \\
\text { (Number) }\end{array}$ & $\begin{array}{r}\text { Building Type 2 } \\
\text { (Hospital) }\end{array}$ \\
\hline 1. Boiler & 0 & 1 \\
\hline 2. Chiller & 5 & 6 \\
\hline 3. Air conditioning & 0 & 10 \\
( package unit) & & \\
\hline 3. Air conditioning & 9,995 & 5,360 \\
\hline
\end{tabular}

\begin{tabular}{|c|r|r|}
\hline ( split type) & & \\
\hline 4. LED lamp & 367,647 & 83,103 \\
\hline
\end{tabular}

\section{Example of successful project}

Rajamangala University of Technology Lanna hired PEA acts to improve and increase energy efficiency by implementing measures to change the light bulbs to LED lamps and changing to use high efficiency air conditioning unit of 6 campuses. Total invest is $\mathrm{BH}$ $72,215,220$ as detailed below.

1. Measure to change the light bulbs by LED lamps is implemented with the invested amount to BH 28,120,320. The payment period is 72 months, with monthly payment of BH 390,560.

2. Measure of using high efficiency air conditioning unit is implemented with the invested amounts to $\mathrm{BH} 44$, 094,900. The payment period is 60 months, with monthly payment of BH 734,915. In summary, both measures are shown in Table 3-4.

\section{Amendment Policy Issue}

It is evident that more than 30 buildings of government buildings Type 2 cannot continue to implement the project. Therefore, we have investigated the legal information, including comments from all relevant government agencies. Then, we compiled and prepared the legislation for the implementation of projects to install high efficiency devices using ESCO system in the building sector. The legislation is used for the implementation by law in the future.

Table 3. Summarizes measure to change the light bulbs to LED

\begin{tabular}{|l|c|c|}
\hline \multicolumn{1}{|c|}{ Description } & unit & 6 Campus \\
\hline Number & tube & 23,471 \\
\hline $\begin{array}{l}\text { The cost of materials } \\
\text { and installation } \\
\text { equipment }\end{array}$ & Baht & $27,067,414$ \\
\hline $\begin{array}{l}\text { The cost of materials } \\
\text { and installation } \\
\text { equipment }\end{array}$ & BH/Tubes & $1,262.93$ \\
\hline $\begin{array}{l}\text { The cost of the } \\
\text { operation. }\end{array}$ & BH/year & $3,007,490$ \\
\hline $\begin{array}{l}\text { Loan rates } \\
\text { Total investments }\end{array}$ & Baht & $30,074,904$ \\
\hline Saving effect & BH/year & $5,476,673$ \\
\hline Payback time & year & 5.49 \\
\hline
\end{tabular}


Table 4. Summarizes Measure of using high efficiency air conditioning unit

\begin{tabular}{|l|c|c|}
\hline \multicolumn{1}{|c|}{ Description } & unit & 6 Campus \\
\hline Number & set & 785 \\
\hline $\begin{array}{l}\text { The cost of materials } \\
\text { and installation } \\
\text { equipment }\end{array}$ & Baht & $39,685,410$ \\
\hline $\begin{array}{l}\text { The cost of the } \\
\text { operation. }\end{array}$ & BH/year & $4,409,490$ \\
\hline Loan rates & \% & 5 \\
\hline Total investments & Baht & $44,094,900$ \\
\hline Saving effect & BH/year & $10,053,457$ \\
\hline Payback time & year & 4.39 \\
\hline
\end{tabular}

We have monitored the implementation of the project of building 53 of and received the information by coordinating with the Provincial Electricity Authority (PEA) and Metropolitan Electricity Authority (MEA) And monitor progress. We found that the establishment of the budget is the barriers. This is contrary to the rules of disbursement to the ordinary project. From the collection of problems such obstacles, we have analysed the recommendations and solutions to proceed the project in the future as follows:

1. Government buildings should establish a budget for the implementation of the project into two parts of data collection and preparation of proposals for the project of high-performance equipment modifications. If the building does not wish to continue the project, the party providers (MEA / PEA) would still have cost in this data collection.

2. The implementation of ESCO is the pattern of hiring a contractor (Lump Sum Turnkey), which according to the Prime Minister on Procurement 1992 Article 54 [4]. Therefore, the project management concept has to be approved by the State Council.

3. To solve the problem of the operational phase of the project within one year engagement according to a financial commitment 1991, the Cabinet has to approve the budget commitments over the year, covering the period of project until the end of the contract period for every government agency.

4. The energy performance contract has to be written by the duration of the contract covering the period of the project. The proposed form of contract also has to be approved by the Cabinet.

5. The budget for utilities should remain constant throughout the project duration. It should be presented to the Cabinet for approval.

6. The savings of the budget for utilities from the project are paid for the cost of energy management of ESCO company. Therefore, the Cabinet has to approve the estimated energy savings according to the authority of the Budget Procedures Act 1959.
7. Various government agencies also implemented the project in different ways. Therefore, there should be regulation of the office of the Prime Minister on the preparation of ESCO project management for energy savings in the building sector for all government agencies by authority of the Government Administration Act 1991[5].

\section{Conclusion}

The preliminary ESCO project management has been launched in order to save energy in the government building sector in 2015. The potential of electricity savings is about 77 million $\mathrm{kwhr} /$ year. It can reduce imports of crude oil about 6.58 thousand tons of crude oil (Ktoe) per year. This represents the cost of BHT 310 million per year. The budget to invest is BHT 1,504 million, with an average payback period of 4.85 The implementation of the project have been monitoring for 53 buildings of by coordinating with PEA and MEA acted as ESCO company. We found that only one building has the successful implementation of the project building. There are 44 buildings that are pending the implementation because of the barriers of budget payment for the cost of ESCO project management. The solutions and guidelines for future project have been analyzed and presented in this paper. The amendment policy in the way of ESCO system for government buildings should be approved by the Cabinet. Finally, the new regulation for establishing the ESCO system is the key to encourage the implementation of energy savings in the buildings.

\section{Acknowledgements}

The paper is based upon work supported by Department of Alternative Energy Development and Efficiency (DEDE) of Thailand.

\section{References}

1. Energy Development and Promotion Act B.E. 2535 (1992), Kingdom of Thailand.

2. Ministerial regulation B.E. 2539 (1996), Ministry of Energy, Kingdom of Thailand.

3. Energy Conservation Promotion Act (No. 2) B.E.2550, Kingdom of thailand.

4. Prime Minister on Procurement 1992 Article 54, Kingdom of thailand.

5. Budget Procedures Act 1959, Kingdom of thailand.

6. C. Asavatesanupap, M. Santikunaporn, and P. Wangsakarn :Energy conservation through valueengineering for SMEs in Thailand, The 5th European Conference Economics and Management of Energy in Industry Proceedings, Vilamoura, Portugal (2009)

7. P. Wangskarn, and M. Sasananan: Comparison of performance-based VS cost-based energy saving project, 2nd WSEAS/IASME International Conference on Energy Planning, Energy Saving, 
Environmental Education (EPESE’08) Corfu, Greece, October 26-28 (2008)

8. Thammasat University: Final Report on the Evaluation the Participatory Energy Conservation Project: Executive Summary (2011)

9. M. Prukvilailert and P. Wangskarn: Energy Conservation Potential in SMEs of Thailand 2011 ,IEEE International Conference on Smart Grid and Clean Energy Technologies (IEEE ICSGCE 2011), Chengdu, China (2011)

10. P. Wangskarn and M. Prukvilailert: Evaluation the Designated Government Buildings Promotion in
Thailand 2011, IEEE International Conference on Smart Grid and Clean Energy Technologies (IEEE ICSGCE 2011), Chengdu, China (2011)

11. How to Hire an Energy Service Company, Energy Efficiency Project Management Handbook, California Energy Commission, Energy Efficiency Division, January 2000, P400-00-001D.

12. D. Gray: How to Hire an Energy Auditor to Identify Energy Efficiency Projects, California Energy Commission, January 2000, P400-00-001C. 